Conference proceedings $2^{\text {nd }}$ and $3^{\text {rd }}$ Regional Innovation \& Entrepreneurship Conference

\title{
Young Generation of Russians: perception of entrepreneurship
}

\section{O.P. Gavrilina, Ph.D}

Russian Presidential Academy of National Economy and Public Administration, Faculty of Service; Department of International Affairs, Institute of Sectoral management

\section{A.V. Shakhrayo}

Russian Presidential Academy of National Economy and Public Administration, Faculty of Real Estate Management; Department of International Affairs, Institute of Sectoral management

Abstract: The authors put forward a hypothesis about absence of fear among modern generation's young people that is connected with impossibility of business in Russia. On the base of the hypothesis authors have conducted a research by projective method within 156 respondents, studying at high school, on the base of which has been conclusion about a necessity of large-scale research in this field received.

Keywords: modern business, young generation, projective method, research, perception, Russia

\section{Introduction}

The research presented in this article has its long background. There is a module in most Russian educational programmes in the field in Economics and Management called "Introduction into Future Profession" where students can get a glance at what they are going to do after their university studies. Course final project given by article authors is about student's "dream employer". So it is a chance for 17- 18 year 
Conference proceedings $2^{\text {nd }}$ and $3^{\text {rd }}$ Regional Innovation \& Entrepreneurship Conference

old to think of the work they really would like to have. Unfortunately, during last 10 years students final presentations were about $\mathrm{P} \& \mathrm{G}$, Unilever, Nike, BMW and other big and famous corporations. And only 3 projects of the dozens were on students' possible entrepreneurial activities or ambitions.

"Starting business in Russia is getting increasingly scary"1, reads the headline of an article recently published in the Russian newspaper Vedomosti. According to Amway Global Entrepreneurship Report 2015, ${ }^{2} 77 \%$ of Russians are afraid of starting their own business, and it is much higher than Europe's similar indicator of $69 \%$. Unfortunately, since the previous research ${ }^{3}$, the percentage of those who are scared of opening their business is up $6 \%$.

It is interesting to note that at present, teaching entrepreneurship in Russia is mainly informal. Formal education is currently represented by the programmes of additional education "Master of business administration" and programme "Economics of entrepreneurship." In addition, few universities and colleges teach specialized courses in entrepreneurship or basic entrepreneurship ${ }^{4}$.

\section{Methodology}

So the research aim was to understand inner motives of avoiding the start of the new business by Russian young generation. To get accurate results authors used one of the most complicated methods of surveying called non-standardized closed questionnaire. For the purposes of the research, we developed a questionnaire (see Annex 1) to be filled out by participants and used the sentence completion method.

This research is designed to focus on young audience (from 17 to 23 years old) studying in an upscale school of economics in a capital city, based on the hypothesis that the young generation does not have serious fears and believes that doing business in Russia is possible and necessary. It was also interesting to find out what the respondents really think of entrepreneurship education and changes in the attitude to education. In addition, the authors chose to use a non-standardised closed

\footnotetext{
${ }^{1}$ Vedomosti, No. 4004 of 29.01.2016, A. Gordeev "Scary Business"

2 Amway Global Entrepreneurship Report, 2015: http://globalnewsassets.amway.com/501484/ager_2015_report.pdf?r=1600

3 Amway Global Entrepreneurship Report, 2013: https://assets1.bywebtrain.com /501522/2013 amway global entrepreneurship report 1.pdf?r=1920

${ }^{4}$ Higher Education in Russia, 2015, No.11, Yu. Rubin "Higher entrepreneurial education in Russia-problem diagnostics"
} 
Conference proceedings $2^{\text {nd }}$ and $3^{\text {rd }}$ Regional Innovation \& Entrepreneurship Conference questionnaire for the interview, and such questionnaire is used to study the respondents' deep motives.

It helps to overcome the unwillingness of those surveyed to discuss their feelings through special techniques, which almost eliminate the dependency of responses on the interviewees' conscience and their willingness not to speak openly. The emphasis in such interviewing techniques known as projection methods is made on hiding the true subject of research by using hidden incentives.

Projective method is the term used to describe the questionnaire that contains hidden incentives, which make respondents rely on their own emotions, needs, motives, preferences and values when they formulate their responses.

Normally, the method implies using standard incentivising questions that can be answered in a very informal manner. That is why the technique is referred to as a "non-standardised closed interview." The main assumption of the technique is that the form used by a person to answer a non-standard incentive question helps finding a key for understanding how the person perceives the example of the research and what is their true attitude to it. ${ }^{5}$

The advantage of the sentence completion method as compared to the association word method is that the respondents can be offered a clearer incentivising motive. Students had to finish sentences without thinking and using not more than 5 words. The statements were:

1. Entrepreneurship is

2. The obstacles to the opening of your own business are

3. To open a business in Russia you need

4. The most attractive country for entrepreneurship is

5. Special education for the entrepreneur

Statistical sampling of the dataset consisted of 3 main groups:

- Bachelor in Management first year students (Freshmen)

- Bachelor in Management last year students (Undergraduates)

- Master students

The survey was conducted over the period 1 December 2015 to 15 February 2016.Authors collected around 150 survey forms and came to very interesting results, as is shown in the paragraph below.

${ }^{5}$ G. Churchill Marketing research, G. Churchill, T. Brown, translation from English edited by G.L. Bagiev, 5th edition, -Spb.: Peter, 2007. p.254 
Conference proceedings $2^{\text {nd }}$ and $3^{\text {rd }}$ Regional Innovation \& Entrepreneurship Conference

\section{$3 \quad$ Findings}

In this paragraph, the findings of the research are debated. After statistical parameters of the sample, the results of the questionnaire is discussed in detail. figure 1 below, the statistical distribution of female and male participants are represented. In figure 2, the age-distribution of the sample is given.

Gender of the research participants, $\%$

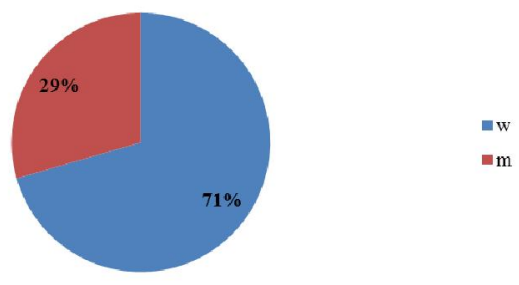

Figure 9

Gender of the research participants, \%

Age of the research participants, units

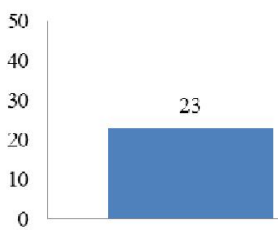

$17-19$ years

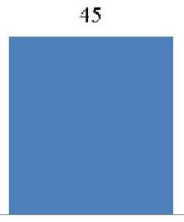

20-23 years
10

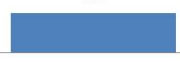

24

Figure 10

Age of the research participants, units

In the tables below, the results of the questionnaire are given in detail. Table 1 shows that the most popular answer is the equation of entrepreneurship with income and money, regardless of the respondents' name.

\begin{tabular}{|l|c|c|c|c|}
\hline No. & $\begin{array}{c}\text { Master's } \\
\text { programme }\end{array}$ & $\begin{array}{c}\text { Under- } \\
\text { graduates }\end{array}$ & Freshmen & Total \\
\hline 1) development of definition & 52 & 7 & 8 & 22 \\
\hline 2) management & 28 & 0 & 48 & 38 \\
\hline 3) creativity & 16 & 4 & 12 & 10 \\
\hline 4) income/ profit/money & 48 & 0 & 31 & 44 \\
\hline
\end{tabular}

Table 1

Understanding the concept of “entrepreneurship”, (\%) 
Conference proceedings $2^{\text {nd }}$ and $3^{\text {rd }}$ Regional Innovation \& Entrepreneurship Conference

Based on the above data, the following conclusion can be drawn: the young generation is aware that entrepreneurship leads to high earnings. It is also important to note that in most attempts to give a formal definition, the respondents mentioned that profit is the main aim. We believe it is natural that masters' students usually gave formal definitions, since they chose to study science. Bachelors' students tend to equate entrepreneurship with management, which is also quite understandable.

The next question was about obstacles to opening business. None of the respondents wrote that there are no obstacles, as is presented in table 2 below. As a rule, they listed several reasons. Young people believe that the most serious obstacle (demotivator) to opening their own business is the lack of seed capital (money). Legislation (obviously the fear is irrational, since nobody directly mentioned that legal framework prevents them from opening their own business) and competition were ranked second and third. Lack of knowledge was mentioned by only $10 \%$ of the respondents, and later $31 \%$ of young people stated that they did not need education or special knowledge. We reviewed the two groups of questionnaires and did not find any inconsistencies: these groups of respondents remain totally separate.

\begin{tabular}{|l|c|c|c|c|}
\hline No. & $\begin{array}{c}\text { Master's } \\
\text { programme }\end{array}$ & Undergraduates & Freshmen & Total \\
\hline 1) lack of idea & 12 & 14 & 100 & 10 \\
\hline 2) no connections & 12 & 0 & 0 & 4 \\
\hline 3) no money & 32 & 39 & 0 & 38 \\
\hline 4) legislation & 24 & 36 & 25 & 29 \\
\hline 5) competition & 28 & 21 & 24 & 24 \\
\hline 6) fear, risk & 24 & 11 & 4 & 13 \\
\hline
\end{tabular}

Table 2

What is an obstacle to open business, (\%)

As to the question regarding opening business in Russia, all the respondents unanimously answered that money is the key driver - 54\%, and $31 \%$ mentioned connections. In the previous question, which did not contain the word "Russia" in it, only $4 \%$ remembered of connections, and the 4 percent were master's students (see table 3). 
Conference proceedings $2^{\text {nd }}$ and $3^{\text {rd }}$ Regional Innovation \& Entrepreneurship Conference

\begin{tabular}{|l|c|c|c|c|}
\hline No. & $\begin{array}{c}\text { Master's } \\
\text { programme }\end{array}$ & $\begin{array}{c}\text { Under- } \\
\text { graduates }\end{array}$ & Freshmen & Total \\
\hline 1) money & 56 & 50 & 56 & 54 \\
\hline $\begin{array}{l}\text { 2) formal answer regarding } \\
\text { procedures }\end{array}$ & 8 & 7 & 12 & 9 \\
\hline 3) idea in place & 12 & 21 & 16 & 17 \\
\hline 4) personal characteristics & 16 & 14 & 20 & 17 \\
\hline 5) connections in place & 36 & 25 & 32 & 31 \\
\hline
\end{tabular}

Table 3

What is required for opening business in Russia, (\%)

It is important to note that the young people from our sample believe that the US is the country with the most attractive climate for small and medium businesses (31\%), and despite all the obstacles, $22 \%$ of them mentioned Russia in this regard, which could mean that with $1 / 5$ of the respondents, desire to work prevails over fear and obstacles (see Table 4 below).

\begin{tabular}{|l|c|c|c|c|}
\hline No. & $\begin{array}{c}\text { Master's } \\
\text { programme }\end{array}$ & $\begin{array}{c}\text { Under- } \\
\text { graduates }\end{array}$ & Freshmen & Total \\
\hline 1) did not think about it & 8 & 0 & 4 & 4 \\
\hline 2) with best taxes & 4 & 4 & 0 & 3 \\
\hline 3) Europe & 24 & 0 & 40 & 35 \\
\hline 4) USA & 28 & 43 & 20 & 31 \\
\hline 5) Russia & 28 & 14 & 24 & 22 \\
\hline 6) Japan & 0 & 4 & 0 & 1 \\
\hline 7) China & 0 & 0 & 8 & 3 \\
\hline
\end{tabular}

Table 4

What is the most attractive country to open a private business, (\%)

In the hypothesis the opinion regarding the need in education for an entrepreneur split - with 28\% answering "preferable" and 31\% saying that education is "not necessary". Among the top qualifications, the respondents listed business and management, and often referred to MBA programme as an example of such education, which, strictly speaking, is not quite accurate, but that is the association that the respondents had (see Table 5).

\begin{tabular}{|l|c|c|c|c|}
\hline No. & $\begin{array}{c}\text { Master's } \\
\text { programme }\end{array}$ & $\begin{array}{c}\text { Under- } \\
\text { graduates }\end{array}$ & Freshmen & Total \\
\hline 1) business & 24 & 25 & 16 & 22 \\
\hline 2) management & 4 & 7 & 12 & 8 \\
\hline 3) finance & 0 & 7 & 4 & 4 \\
\hline 4) law & 8 & 7 & 20 & 12 \\
\hline 5) not necessary & 20 & 32 & 40 & 31 \\
\hline 6) preferably university degree & 52 & 11 & 24 & 28 \\
\hline
\end{tabular}

Special education for an entrepreneur, (\%) 
Conference proceedings $2^{\text {nd }}$ and $3^{\text {rd }}$ Regional Innovation \& Entrepreneurship Conference

\section{Conclusion}

In conclusion, it is important to note that no differences in the responses based on ages were identified. The research data are qualitative and reconnaissance by nature, and provide grounds for a further large-scale survey.

\section{References}

1. Daily newspaper Vedomosti; article by A. Gordeev published in No. 4004 of 29.01.2016, under the headline "Scary Business"

2. Yu. Rubin Higher Education in Russia, 2015, No.11, article "Higher entrepreneural education in Russia - problem diagnostics."

3. G. Churchill Marketing research, G. Churchill, T. Brown, translation from English edited by G.L. Bagiev, 5th edition, -Spb.: Peter, 2007. p.254

4. Amway Global Entrepreneurship Report, 2015.

5. Amway Global Entrepreneurship Report, 2013. 